(1)

\title{
退化高寒草地的近自然恢复: 理论基础与技术途径
}

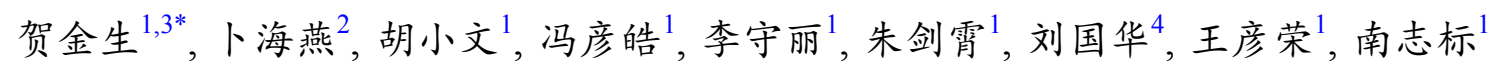

1. 兰州大学草地农业与科技学院, 草地农业生态系统国家重点实验室, 兰州 730020;

2. 兰州大学生命科学学院, 草地农业生态系统国家重点实验室, 兰州 730000;

3. 北京大学城市与环境学院, 北京 100871 ;

4. 中国科学院生态环境研究中心, 城市与区域生态国家重点实验室, 北京 100085

*联系人, E-mail: jshe@pku.edu.cn

2020-06-11 收稿, 2020-07-20 修回, 2020-07-21 接受, 2020-07-22 网络版发表

国家重点研发计划(2019YFC0507701)资助

摘要 近几十年来, 青藏高原高寒草地植被活动整体上趋于向好, 但大部分草地仍然存在不同程度的退化, 局部有 恶化的态势. 在青藏高原生态屏障保护与建设过程中, 由于建植或改良的草地草种单一、优良乡土草种少, 加之受 高寒气候的限制, 群落稳定性和可持续性不强, 使得生态系统多功能性和多服务性往往难以完全恢复. 因此, 探索 行之有效的可持续恢复模式迫在眉睉. 本文提出了对青藏高原高寒草地实施近自然恢复(close-to-nature restoration) 的理念, 从生物多样性、生态系统多功能性和多服务性、生态系统稳定性的理论出发, 结合青藏高原高寒生态系 统的特点, 论述了近自然恢复是退化高寒草地生态恢复的必然选择. 据此, 本文提出优良乡土草种扩繁、组配及其 补播技术是高寒草地近自然恢复技术亟须解决的瓶颈，土壤养分及微生物调控相结合是“近自然恢复”技术的重要 辅助措施. 该理论与技术途径为青藏高原退化高寒草地生态系统恢复提供了一个基于自然的解决方案.

关键词近自然恢复, 高寒草地, 生物多样性, 生态系统多功能性, 生态系统多服务性, 乡土草种

\section{1 生态系统近自然恢复(close-to-nature restoration)理念的形成}

20世纪60年代，世界各地尤其是欧洲、北美洲对 土地的过度利用导致的一系列环境问题，引起了人们 的重视. 人们开始进行自然生态系统保护、退化生态 系统整治与恢复等方面的研究. 受损生态系统传统恢 复方式有自然恢复、人工辅助的恢复、生态工程 3 种 方式 ${ }^{[1]}$ : (1) 自然恢复是指受损生态系统在不受人类干 扰的情况下，依靠自然演替来恢复已退化的生态系统， 例如, 围封森林或草原使这些地区不受人类活动的影 响，促进自然更新，这种方法恢复的生态系统稳定性 高, 但通常恢复过程漫长; (2) 人工辅助的恢复是指通
过人工辅助措施恢复退化生态系统，如补播、施肥等; （3）生态工程是指根据生态学原理, 通过工程设计, 重 建生态系统, 如人工草地建植. 后两种方法也是世界各 国普遍采用的退化生态系统恢复技术，通常生态系统 恢复过程较快，但由于补播物种单一、生物人侵、管 理不当等问题，导致群落稳定性较差或对生态系统产 生较大的干扰, 甚至导致更严重退化, 以致恢复工作投 人的人力物力被大量浪费 ${ }^{[2,3]}$. 随着对退化生态系统恢 复过程研究的不断深人，人们意识到各类技术措施的 应用不能仅考虑经济效益及短期的恢复成效，必须重 视恢复后生态系统应对灾害风险的弹性.

近年来，“近自然恢复”理念受到世界各国生态学 家们的普遍关注. 近自然恢复是指基于生态学理论, 通 
过科学有效的人工辅助及管理措施，依靠自然生态过 程, 把退化生态系统恢复到物种组成、多样性和群落 结构与地带性群落接近的生态系统, 从而实现恢复后 生态系统结构和功能的多样性、稳定性和可持续性. 近自然恢复理念起源于 19 世纪德国 ${ }^{[4]}$, 并于 20 世纪中后 期在欧美国家得到广泛应用的“近自然林业(close-tonature silviculture/forestry)”理念 ${ }^{[5]}$. “近自然林业”强调 森林管理应该“回归自然(back to nature)”, ${ }^{, 4]}$, 提倡利用 不同种类、不同龄级的适生树种营造接近于自然林的 混交林从而实现可持续和高效的管理，而不是传统的 皆伐(clear cutting)后种植同龄纯林的模式 ${ }^{[4,6]}$. 从20世 纪90年代, 近自然恢复这一理念也引起我国学者的兴 趣，并将其应用于我国退化生态系统恢复、管理与利 用 ${ }^{[7 \sim 9]}$.

随着对人与自然之间辩证关系研究的不断深人, 以技术手段进行生态保护与治理的观念逐渐改变, 人 们开始着眼于人与自然协调发展, 逐渐发展了一种新 的理念——基于自然的解决方案”(nature-based solutions，NBS). 欧盟将NBS定义为“一种受到自然启发、 支撑并利用自然的解决方案，以有效和适应性手段应 对社会挑战, 增强社会的韧性, 提高经济、社会和环境 效益” ${ }^{[10]}$. 该《方案》提倡依靠自然进行生态治理, 着 眼于可持续发展, 其宗旨与近自然恢复理念相一致. 事 实上，近自然恢复理念提倡更多依靠自然过程进行生 态治理，着眼于生态系统功能和服务的多样性以及恢 复的可持续性, 本身就是基于自然的解决方案. NBS可 以说是以近自然恢复理念为基础，通过因地制宜、资 源有效利用及系统性干预等措施，将近自然恢复理念 应用于各类生态系统中.

近自然恢复并不是完全摒弃传统人工恢复，而是 着眼于长期目标, 以生态保护为前提, 通过理念指导, 将维护生物多样性和提升生态系统多功能性与多服务 性作为首要任务, 借助传统人工恢复措施, 依靠自然生 态过程, 尤其是以生物多样性为核心的生态过程, 进行 可持续生态恢复. 退化草地修复过程中, 多通过建植单 一物种或少数几个物种的人工草地快速恢复植被，虽 然群落生产力水平大大提高了, 但生物多样性低、生 态系统固碳和水源涵养能力都不高 ${ }^{[11 ~ 13]}$ (图1). 近自然 恢复注重“基于自然”和“回归自然”，更多利用自然生 态系统是自调节(self-regulating)系统的属性, 引导退化 生态系统重新进行组织, 通过自我调节实现可持续恢 复 ${ }^{[5,14]}$. 因此, 近自然恢复后的生态系统具有较高的生

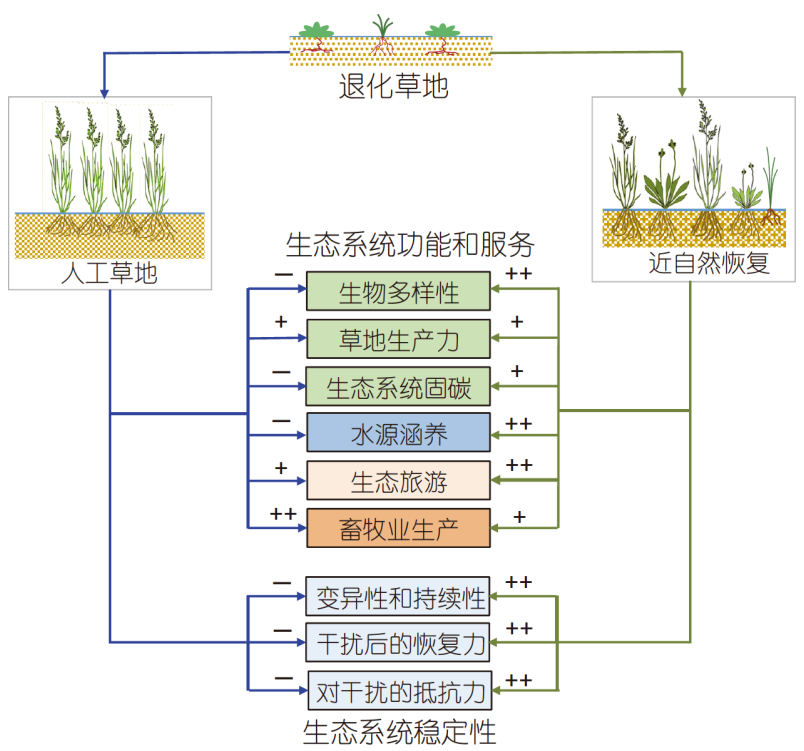

图 1 (网络版彩色)退化草地近自然恢复与人工草地对生态系统功 能和服务的作用比较

Figure 1 (Color online) Comparison of the effects of close-to-nature restoration vs. artificial grassland (traditional restoration) on ecosystem functions and services

物多样性, 能够提供更多生态系统功能和服务, 并增加 应对灾害风险的弹性(图1). 例如，对于草地生态系统， 近自然恢复不仅能提高草地生产力，也可大幅度改善 草地生态系统多种功能和服务, 如提高物种多样性、 增加生态系统固碳功能、提高草地水源涵养能力及草 地的景观多样性等(图1).

\section{2 近自然恢复是高寒草地生态恢复的必然 选择}

\section{1 高寒草地生态恢复的现状}

近几十年来, 在人类活动(如过度放牧和开剭)和环 境变化(如全球变暖)的双重压力下, 青藏高原高寒草地 植被、土壤退化严重, 生物多样性降低、生产力下降, 当地生态和经济受到严重威胁 ${ }^{[15 ~ 18]}$. 对于高寒退化草 地, 目前的恢复措施主要包括人工补播、封育、轮 牧、施肥、划破草皮等 ${ }^{[19]}$. 尽管这些恢复措施短期也 起到缓解草地退化、提高生产力等效果，但存在恢复 后生态系统功能和服务单一、稳定性差等问题, 加之 对高寒草地特有属性关注不足，难以实现可持续性恢 复 ${ }^{[3]}$. 首先, 这些措施恢复后的高寒草地生态系统功能 和服务单一. 例如, 构建单一的禾本科牧草地, 如垂穗 
披碱草(Elymus nutans)、中华羊茅(Festuca sinensis)、 老芒麦(Elymus sibiricus)、紫羊茅(Festuca rubra $)^{\text {等 }}{ }^{[3]}$. 这些恢复措施尽管能在短时间内快速恢复高寒退化草 地植被盖度及生产力，但由于补播物种单一或未充分 考虑物种或功能群间的综合配比，外加草地管理措施 不够合理, 所构建群落物种多样性低, 使得恢复后生态 系统功能和服务也较为单一. 其次, 传统措施恢复后的 高寒草地生态系统稳定性和可持续性较差. 例如, 在青 藏高原高寒退化草地恢复过程中，构建物种单一的人 工草地、补播单一禾本科植物和简单的封育等措施可 以起到快速建植、覆盖裸露地表的作用，但恢复后群 落和生态系统往往稳定性较差 ${ }^{[20]}$. 一旦开始放牧、割 草等活动, 这些恢复后的高寒草地状态往往迅速回落, 甚至劣于恢复前状态 ${ }^{[3,20]}$. 最后, 高寒草地处于寒冷、 紫外线强、昼夜温差大等极端的环境条件，因此在一 些属性上与其他草地有所不同. 例如, 与其他环境较为 温和的草地植物之间主要以竞争关系为主相比, 青藏 高原高寒草地植物群落物种间具有较强的正相互作用 (facilitation) ${ }^{[21]}$. 传统的恢复手段往往对这些特异性关 注不足, 因此难以达到理想的恢复效果. 综上所述, 目 前的高寒退化草地恢复存在诸多不足, 因此探索行之 有效的新恢复模式迫在眉睫.

\section{2 高寒草地近自然恢复的必要性}

近自然恢复从自然系统自我调节的角度充分考虑 并借助自然过程, 尤其是生物多样性和群落组成介导 的生态过程, 实现可持续恢复. 以下从实现恢复后生态
系统的稳定性、多功能性和多服务性以及青藏高原高 寒草地生态系统特点等方面, 阐明对高寒退化草地进 行近自然恢复的必要性.

\subsection{1 近自然恢复有望确保高寒退化草地实现稳定} 和可持续恢复

退化生态系统恢复的目标是把受损生态系统的结 构和功能恢复到受人为干扰前的状态, 具有受干扰时 抵抗偏离及返回初始态的能力(稳定性), 并在合理利用 的情况下, 可以长久保持自身结构和功能相对稳定的 能力(可持续性). 近自然恢复由于能更好地维持生物多 样性，有望更好实现恢复后生态系统的稳定和可持续 性 $^{[2224]}$. 大量的长期野外实验发现, 生物多样性高的生 态系统, 其群落生产力稳定性更高, 对环境变化的抵抗 力和恢复力也更强 ${ }^{[22,23,25 ~ 27]}$. 例如, Isbell等人 ${ }^{[27]}$ 的研究 结果表明, 高的生物多样性增加了生态系统对环境变 化的抵抗力, 包括干旱、极端环境、短期或长期的气 候变化等. 近期在青藏高原高寒草地进行的研究也表 明，生物多样性对维持生态系统稳定性至关重要。例 如, Shi等人 ${ }^{[28]}$ 通过青藏高原高寒草地 40 个地点连续 4 年的生物量监测, 发现在区域尺度上群落物种丰富度 和生产力稳定性间有正相关关系. 再如， Liu等人 ${ }^{[29]}$ 利 用青藏高原高寒草甸32年生物量的监测数据, 发现尽 管气候有明显的暖干化趋势, 但研究地点草地生物量 保持相对稳定，这得益于不同功能群间、特别是不同 根系深度植物间的补偿作用，保证了干旱年份和湿润 年份生物量的相对稳定(图2). 这些经验都表明, 为了 实现高寒草地恢复后生态系统的稳定性, 需要在恢复

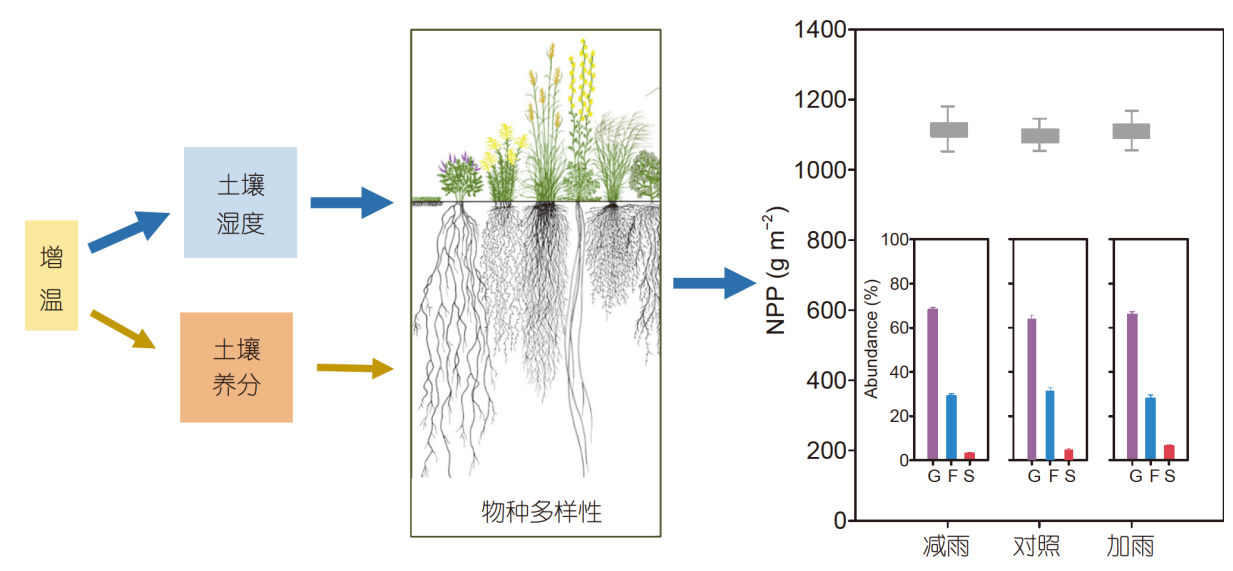

图 2 (网络版彩色)高寒草地不同功能群间的互补作用在生产力稳定性维持中具有重要作用. 主要根据Liu等人 ${ }^{[29]}$ 数据总结, 减雨(-50\%)、加 雨 $(+50 \%)$ 处理并没有改变生态系统的净初级生产力(NPP). G = grasses; F= Forbes; $\mathrm{S}=$ sedges

Figure 2 (Color online) The compensatory effect of different functional groups in alpine grassland plays an important role in maintaining productivity stability. This figure is mainly based on the data from Liu et al. ${ }^{[29]} . \mathrm{G}=$ grasses; $\mathrm{F}=$ Forbes; $\mathrm{S}=$ sedges 
过程中充分考虑生物多样性的效应，而不是忽视自然 过程的作用.

生物多样性促进生态系统稳定性的机制主要是通 过缓冲效应和补偿效应来实现. 首先, 多样性较高的群 落包含更多具有独特生活史策略的物种, 可以抵御环境 扰动 ${ }^{[23,30 ~ 32]}$, 从而通过缓冲作用保证在经受胁迫后群落 的快速恢复能力. 其次, 不同物种对环境波动的响应不 同，在物种丰富的群落中，某些物种生物量的减少更有 可能由其他物种生物量的增加来补偿 ${ }^{[33 ~ 35]}$. 换句话说, 不同物种对环境波动的响应不同可能造成异步性(asynchrony), 从而保证整个群落的稳定性 ${ }^{[22,32,36,37]}$. 因此, 对 高寒草地进行近自然恢复不仅要考虑生物多样性本身, 还要考虑乡土草种对环境波动的响应以及群落组成, 才 能实现恢复后生态系统的稳定性和可持续性.

2.2.2 近自然恢复是维持生态系统多功能性、多服 务性的要求

对于退化生态系统的恢复，另一个关键问题是如 何实现恢复后生态系统多功能性和多服务性. 自然生 态系统往往具有多功能性(如生产力、元素循环、涵 养水源等 ${ }^{[38 \sim 40]}$, 具有同时为人类提供多重服务的能力 (如经济、旅游等 $)^{[41]}$ ，本文定义为生态系统多服务性 (ecosystem multiserviceability)(图3). 作为高海拔优势 的生态系统，青藏高原高寒草地生态系统提供包括畜 牧业生产、旅游在内的诸多生态、经济功能和服

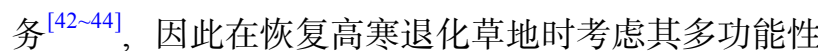
和多服务性十分重要.

20 世纪 90 年代以来的生态学理论普遍认为, 生物 多样性和群落组成对维持生态系统多功能性和多服务 性至关重要 ${ }^{[45 ~ 47]}$, 而且这也得到国内外大量长期和短 期野外实验的广泛证明 ${ }^{[22,38,39,48-52]}$. 以生物多样性为核 心的生态学过程对生态系统功能的作用主要通过补偿 效应和选择效应实现：前者是由于不同物种之间生态 位的差异造成的，后者是由于具有特定性状的物种占 优势造成的 ${ }^{[53]}$. 近自然恢复由于能更好地恢复退化草 地的生物多样性和群落组成, 因此能够更好地维持生 态系统多功能性和多服务性. 具体而言, 近自然恢复有 望使得高寒草地生态系统保持更高的生产力, 更好地 抵御外来人侵物种, 更好地涵养水源, 调节生态系统碳 氮磷等元素循环, 实现生产、生态和经济的协同发展.

\subsection{3 近自然恢复是高寒草地在极端环境下的必然} 选择

植物间的相互作用是影响自然种群及群落结构和

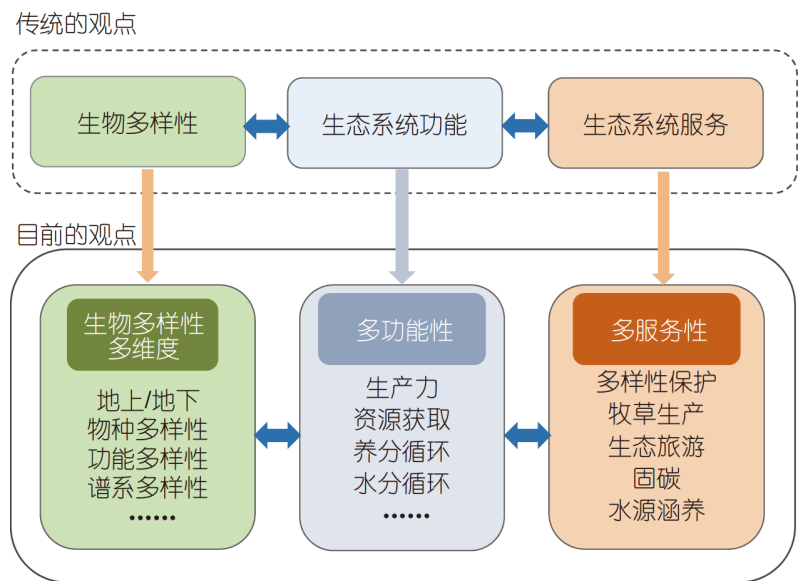

图 3 (网络版彩色)生物多样性与生态系统多功能性、多服务性. 传 统上认为, 生物多样性和生态系统功能密切联系, 它们又是生态系统 服务的基础. 现在学科的发展, 生物多样性不仅考虑多个维度, 还特 别强调地下的生物多样性; 生态系统功能则考虑多功能性; 生态系统 服务也同时考虑提供多服务性的能力

Figure 3 (Color online) Biodiversity and ecosystem multifunctionality and multi serviceability. Traditionally, biodiversity and ecosystem functions are closely linked, and they are the basis of ecosystem services. With the development of the discipline, biodiversity not only considers multiple dimensions, but also emphasizes underground biodiversity; ecosystem functions consider multifunctionality; and ecosystem services also consider the ability to provide multiple services, which we define as ecosystem multi serviceability

动态的主要驱动力. 长期以来, 物种间的负相互作用(即 竞争)在物种多样性维持及群落结构稳定中的作用得 到了绝大多数生态学家的认可, 相关研究极大地推动 了生态学的发展 ${ }^{[54]}$. 然而, 在自然界, 相邻的植物不仅 会竞争光照、水分、营养等，也会互相帮助，例如，增 加传粉者数量、通过冠层保护幼苗、降低食草动物的 负面影响以及通过菌根互助等. Bertness和Callaway ${ }^{[55]}$ 提出了一个概念模型——环境胁迫梯度假说(stress gradient hypothesis)，指出在较好的环境条件下，物种间以 负相互作用(如竞争)为主; 而随着环境胁迫程度的增 加, 物种间正相互作用变得更加重要(图4). 这一假说 在很多胁迫环境下(高山、苔原、沼泽、干旱区、盐 碱地等)的研究中得到证实 ${ }^{[56-61]}$. 青藏高原气候寒冷、 紫外线强、昼夜温差大，极端的环境条件使该区域成 为我国陆地生态系统的脆弱区. 研究证明, 青藏高原高 寒草地植物群落物种间具有较强的正相互作用 ${ }^{[21]}$. 随 着海拔的增高, 温度逐渐降低, 土壤贫痊且持水性差, 生长季缩短，环境压力变大，适宜生存的植物种类减 少，生物多样性降低，物种之间的竞争变得不再重要， 转而通过互相帮助以对抗恶劣环境, 增加生存机会 


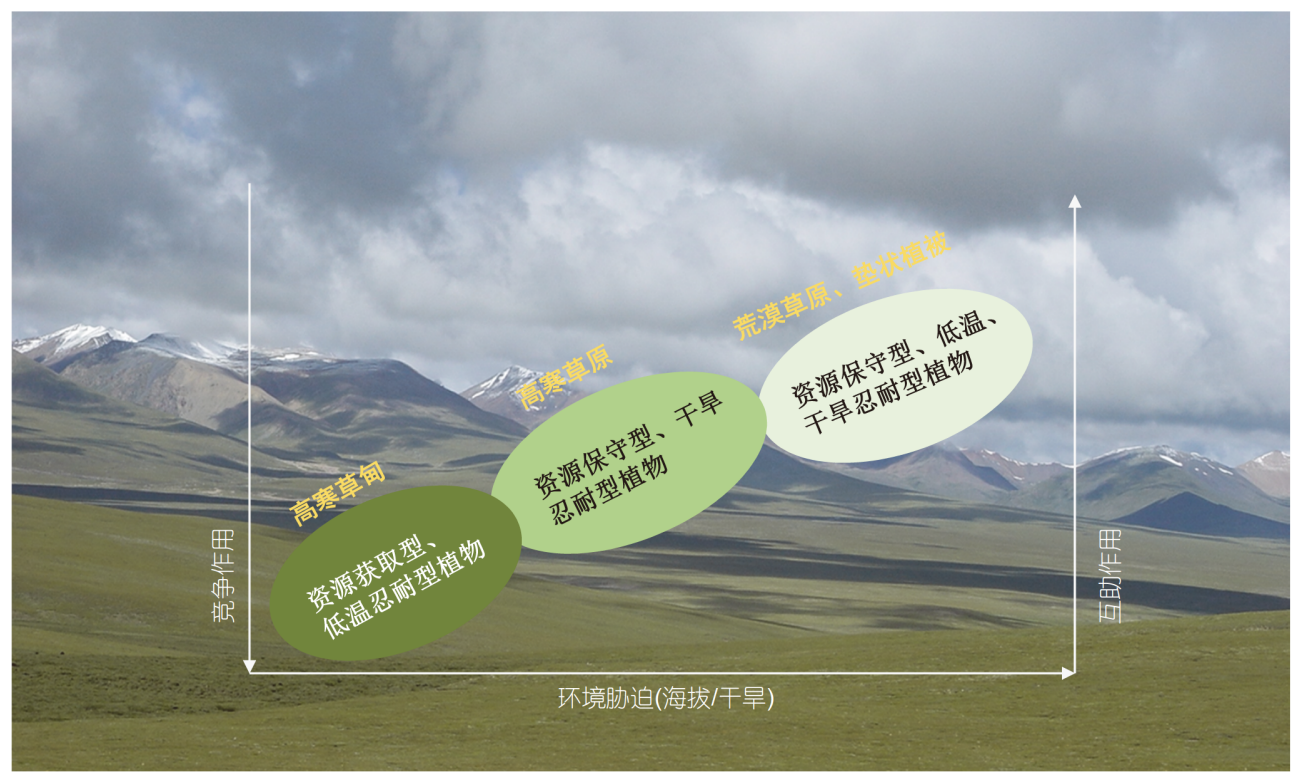

图 4 (网络版彩色)植物之间的相互作用与环境胁迫梯度有关. 随着环境胁迫的增强,物种间互助作用逐渐增强, 而竞争作用减弱. 相应地, 不同 的环境胁迫下选择了不同生活史策略的植物. 背景图是青藏高原高寒草地的典型景观

Figure 4 (Color online) Plant interactions are related to environmental stress gradients. With the increase of environmental stress, mutual assistance between species has gradually increased, while competition has weakened. Correspondingly, plants with different life history strategies were selected under different environmental stresses. The background photo is a typical landscape of the alpine grassland on the Tibetan Plateau

(图4).

近年来，越来越多的生态学家认识到物种间的“相 互帮助”对群落结构的形成与生物多样性的维持也至 关重要, 尤其是在严酷的环境中 ${ }^{[56,62,63]}$. 物种之间的正 相互作用可以减轻局部环境的胁迫压力，益于其他物 种的生存, 扩大物种的实际生态位 ${ }^{[59]}$, 从而提高物种多 样性、影响群落组成及稳定性 ${ }^{[62,64]}$. 此外, 物种间的正 相互作用可以通过提高群落物种多样性, 进而提高群 落生产力及抗干扰能力 ${ }^{[65,66]}$, 这恰恰是退化生态系统 修复的终极目标. 因此, 利用物种间的正相互作用可能 是青藏高原退化生态系统恢复的有效手段 ${ }^{[63]}$.

\section{3 高寒草地近自然恢复的瓶颈及建议途径}

\section{1 优良乡土草种种源限制及克服的途径}

近自然恢复的核心理念在于根据群落演替理论, 利用乡土物种, 把退化草地恢复到物种组成、多样性 和群落结构与地带性植被接近的生态系统. 因此, 应用 与恢复区域环境相适应的乡土草种来进行草地恢复是 达成这一目标的关键 ${ }^{[67,68]}$. 但对于大规模的生态恢复 实践而言，无论是免耕补播，还是人工草地的建植，由 于可利用草种少、种子质量低以及机械化播种难度大
等导致的补播群落组成单一、稳定性差、种子出苗及 存活率低、补播技术不易推广等问题，已成为限制退 化高寒草地“近自然恢复”的技术瓶颈。应用乡土草种 进行草地的近自然恢复通常涉及的核心技术包括适宜 种源的采集、扩繁、收获、清选加工、播种及物种组 配等，每一个环节的成败都直接或间接影响了近自然 恢复目标的实现(图5).

首先，适宜的种源是确保目标种群稳定和持续的 前提，一般要求种子来源于恢复目标区域或者目标区 域的附近 ${ }^{[69,70]}$. 而通常情况下，目标区域往往难以提供 足量的种子, 即使通过野外采集能够满足局部需要, 也 非常昂贵, 难以大规模应用. 目前解决这一问题的主要 途径有 3 个. 其一, 研发小型轻便式收获机械, 提高田间 条件下的种子收集效率，降低种子采集成本. 如采用一 种类似吸尘器的手持式真空收获装置可有效提高草地 种子采集效率 ${ }^{[71]}$. 其二, 从野外采集乡土草种, 人工栽 培条件下集约化扩繁, 可有效提高种子产量和质量, 如 我国青藏高原地区的垂穗披碱草 $(E$. nutans $)$ 、老芒麦 (E. sibiricus)、中华羊茅 $(F$. sinensisi)、草地早熟禾 (Poa pratensis)、星星草(Puccinellia tenuiflora) 等均已 实现商业化生产 ${ }^{[2]}$, 成本大幅降低, 这可能已成为解决 乡土草种供应最为有效的途径. 其三, 即使是植被条件 

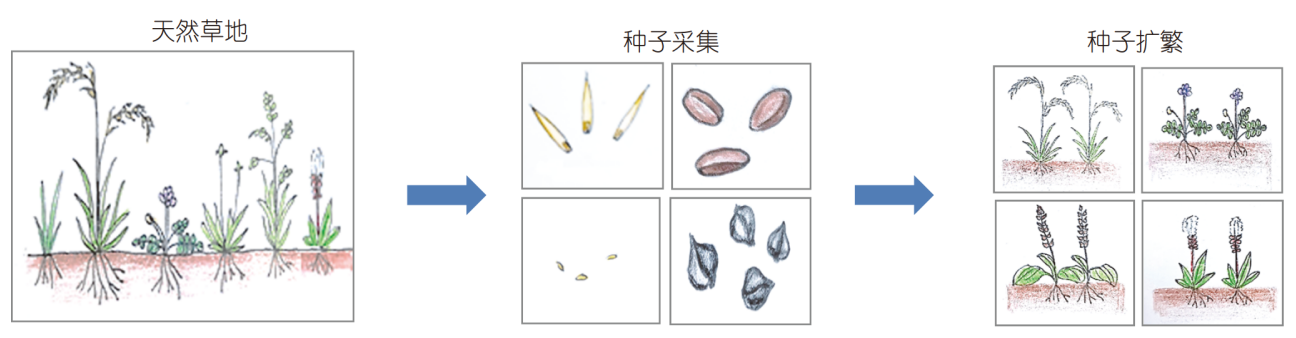

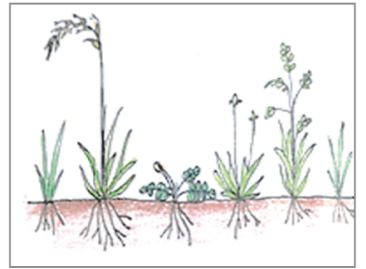

恢复草地

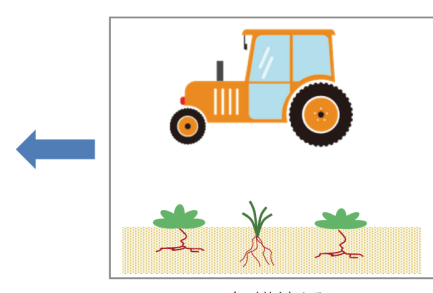

免耕补播

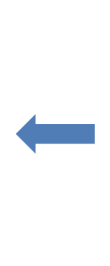
图 5 (网络版彩色)草地近自然恢复的瓶颈及实现途径. 乡土草种种子采集技术、扩繁技术、种子包衣技术及组配技术、免耕补播技术, 还存
在一系列的技术难题需要攻克. 需要指出, 高寒草地有些物种结实率很低, 如高草, 主要以克隆繁殖为主, 这些物种的扩繁问题一直没有解决 Figure 5 (Color online) Bottlenecks and approaches to close-to-nature restoration of grassland. There are also a series of technical problems that need to be overcome, including seeds collection, propagation, and assembly and mechanized sowing of native species. It should be pointed out that some species of alpine grassland have very low seed setting rate, such as species from Kobresia, which mainly relies on clonal reproduction. The problem of the propagation of these species has not been solved

相对较好的草地，由于放牧等原因, 其种子产量往往非 常有限, 因而也可借鉴林地管理的措施, 划定特定区域 作为种子供应地，通过施肥等人工干预措施提高种子 供应地的种子产量 ${ }^{[72]}$.

其次，高寒草地乡土草种普遍具有休眠性，且种子 相对较小, 存在出苗率低、不宜进行机械化播种等问题. 因而，明确种子休眠特性，播种前采取适当的破除休眠 方法有助于提高种子在田间的出苗率. 此外, 应用种子 引发、包衣、丸粒化等技术一方面可以提高种子活力 以及种子在幼苗期对病虫害与非生物逆境的抗性, 另一 方面也可以通过丸粒化提高小种子机械播种性.

最后，适宜的播种技术是决定种子出苗、进而影 响生态恢复效果的另一关键. 与传统的人工草地建植 不同，近自然恢复过程应尽可能减少对草地原有生境 的干扰. 依据环境条件不同，应选择合适的播种方式. 对于相对平坦的草地，机械化播种是一种快速且经济 有效的方法, 但这一过程应尽可能避免机械对草地的 破坏，如采用免耕补播技术可减少开沟对草地的破坏。 但在高寒草地, 如何在复杂的草地生境, 确保适宜的播 种深度、播种过程中特别是在多物种混播的情况下均 匀下种等仍是机械播种有待改进的技术难题. 对于坡 地或者机械不易到达的区域，可采用人工撒播的方式，
但这样通常使种子悬于草层表面, 不易萌发建植, 一个 常用的方法是将家畜引入进行践踏，以促进种子与地 面的接触.

\section{2 土壤养分及微生物调控相结合是“近自然恢复” 的重要辅助措施}

草地退化不仅仅是植被退化，更严重的是土壤的 退化. 随着地上植被的退化, 地下生物量也向土壤表层 聚集, 改善土壤结构与肥力的土壤微生物种类及数量 大幅减少，土壤含水量、紧实度及土壤养分显著降低, 水土流失加剧, 从而加速草地植被退化过程, 形成恶性 循环. 因此, 要实现退化草地生态系统的恢复, 除了上 面提到的种源调控，土壤养分和微生物调控相结合就 非常重要.

首先要明确不同退化生态系统土壤养分的限制因 子. 土壤氮 $(\mathrm{N})$ 磷 $(\mathrm{P})$ 等养分分布具有明显的时空异质 性，明确不同类型退化草地恢复过程中的限制性元素 是研发养分调控技术的关键环节. 除了土壤有效 $N$ 、有 效P的含量, 土壤 N:P比值也是判断养分限制状况及哪 种养分限制了有机质分解的重要指标 ${ }^{[73]}$. 在明确退化 高寒草地土壤养分及其化学计量学关系限制以后，可 制定针对性地进行“测土施肥”措施. 对于退化严重的 
草地, 通过各种措施例如划破草皮或深松等, 改造土壤 的物理结构, 活化土壤养分, 提高养分的有效性, 是更 为有效的恢复手段 ${ }^{[74]}$.

土壤微生物是土壤有机质和养分循环的主要驱动 者, 对生态系统的物质循环具有不可替代的作用. 但是 退化生态系统破坏了植物和微生物的互作关系 ${ }^{[75]}$, 研 发以菌肥和有机肥添加为基础的土壤微生物改良技 术, 可以提高土壤肥力, 使退化草地地下生物多样性尽 快得到恢复, 促进生态系统尽快重返自然状态. 有研究 表明，土壤好气性自生固氮菌和嫌气性自生固氮菌的 数量随草地退化程度的加重而减少, 土壤固氮菌相对 于土壤总细菌的比例也有降低的趋势 ${ }^{[76]}$. 这说明退化 草地土壤多功能性的恢复、土壤微生物的调控是 关键.

这里需要指出, 实际操作中应该注意以下几点: (1) 草地退化涉及“土壤-植被-家畜”整个系统，退化草地的 恢复, 放牧管理是第一位的. 要依据草地的轻度、中 度、重度退化程度, 分别采用围栏休牧、围栏封育、 生物和非生物调控管理措施 ${ }^{[77]}$. (2) 不管是处于极度退 化草地, 还是轻、中、重度退化草地, 生态恢复都可以
采用近自然恢复的理念，依据生态系统所处的退化阶 段，选择该演替阶段的优势乡土物种，辅助于人工措 施，促进生态系统的演替进程. 如果草地退化比较严 重, 除考虑植物、微生物因素外, 还要考虑土壤物理结 构等的恢复. 在人工措施改良土壤的基础上, 选择基于 不同功能性状、不同功能群的物种，更好地利用资 源 ${ }^{[51,78]}$, 实现草地群落的多功能性和多服务性. (3) 本 文着重论述了近自然恢复是退化高寒草地生态恢复的 必然选择，由于高海拔、低温、群落生产力低下、土 壤发育缓慢的特点，退化高寒草地更需要利用自然的 力量, 最大限度地减少对生境的破坏, 特别是对土壤的 破坏进行恢复.

总之, 对于退化高寒草地, 首先需要明确不同退化 程度和类型草地恢复的限制因子; 其次, 需要研发草地 恢复的技术体系，包括乡土草种扩繁、组配及补播、 土壤质量提升及放牧管理等方面的技术、具体包括研 发以乡土草种优化配置和免耕补播为基础的高效补播 技术、以微生物菌肥和关键养分添加为基础的土壤质 量提升技术、高寒草地有害生物防控技术、草地可持 续放牧管理技术, 实现可持续的近自然恢复.

\section{参考文献}

1 Ren H, Liu Q, Li L H, et al. Introduction to Restoration Ecology (in Chinese). 3rd ed. Beijing: Science Press, 2019 [任海, 刘庆, 李凌浩, 等. 恢复 生态学导论. 第3版. 北京: 科学出版社, 2019]

2 Shang Z H, Dong Q M, Shi J J, et al. Research progress in recent ten years of ecological restoration for "black soil land" degraded grassland on Tibetan Plateau-Concurrently discuss of ecological restoration in Sangjiangyuan region (in Chinese). Acta Agrest Sin, 2018, 26: 1-21 [尚占环, 董全民, 施建军, 等. 青藏高原“黑土滩”退化草地及其生态恢复近10年研究进展——兼论三江源生态恢复问题. 草地学报, 2018, 26: 1-21]

3 Zhang Q, Ma L, Zhang Z H, et al. Ecological restoration of degraded grassland in Qinghai-Tibet alpine region: Degradation status, restoration measures, effects and prospects (in Chinese). Acta Ecol Sin, 2019, 39: 7441-7451 [张骞, 马丽, 张中华, 等. 青藏高寒区退化草地生态恢复: 退化 现状、恢复措施、效应与展望. 生态学报, 2019, 39: 7441-7451]

4 Gayer K. Der gemischte Wald, seine Bergründung und Pflege, insbesondere durch Horst-und Gruppenwirtschaft. Berlin: Parey, 1886

5 Remeš J. Development and present state of close-to-nature silviculture. J Landsc Ecol, 2018, 11: 17-32

6 Schütz J P, Saniga M, Diaci J, et al. Comparing close-to-naturesilviculture with processes in pristine forests: Lessons from Central Europe. Ann Forest Sci, 2016, 73: 911-921

7 Shao Q H. A boom of “nature-approximating forestry” in middle Europe (in Chinese). World For Res, 1991, 4: 8-15 [邵青还. 第二次林业革命 —“接近自然的林业”在中欧兴起. 世界林业研究, 1991, 4: 8-15]

8 Zhang S X, Lei R D, Chen C G, et al. "Near-nature forest"-A promising “man-made nature forest" (in Chinese). J Northwest For Univ, 1996, (S1): 157-162 [张硕新, 雷瑞德, 陈存根, 等. “近自然林”——种有发展前景的“人工天然林”. 西北林学院学报, 1996, (S1): 157-162]

9 He L, Bin J, Deng D Z, et al. Review on progress in vegetation close-to-nature recovery (in Chinese). J Sichuan For Sci Technol, 2017, 5: 22-26 [贺丽, 宾建, 邓东周, 等. 植被近自然恢复研究进展. 四川林业科技, 2017, 5: 22-26]

10 European Commission. Towards and EU Research and Innovation Policy Agenda for Nature-based Solutions and Re-naturing Cities. Final Report of the Horizon 2020 Expert Group on "Nature-Based Solutions and Re-naturing cities", 2015. 74

11 Dong Q M, Ma Y S, Zhao X Q. Study on management technology for "black-soil-type" degraded artificial grassland in Yangtze and Yellow River Headwater Region (in Chinese). Pratac Sci, 2007, (8): 9-15 [董全民, 马玉寿, 赵新全. 江河源区“黑土型”退化人工草地管理技术研究. 草业科 学, 2007, (8): 9-15]

12 Ma Y S, Shang Z H, Shi J J, et al. Studies on allocate skills of artificial community of "black soil type" degraded grassland in the Yellow River 
Source Region (in Chinese). Acta Agric Boreali-Occidentalis Sin, 2007, 16: 1-6 [马玉寿, 尚占环, 施建军, 等. 黄河源区 “黑土型”退化草地人工 群落组分配置技术研究. 西北农业学报, 2007, 16: 1-6]

13 Shang Z H, Ma Y S, Long R J, et al. Effect of fencing, artificial seeding and abandonment on vegetation composition and dynamics of 'black soil land' in the headwaters of the Yangtze and the Yellow Rivers of the Qinghai-Tibetan Plateau. Land Degrad Dev, 2008, 19: 554-563

14 Schütz J. Close-to-nature silviculture: Is this concept compatible with species diversity? Forestry, 1999, 72: 359-366

15 Wang Y B, Wang G X, Shen Y P, et al. Degradation of the eco-environmental system in alpine meadow on the Tibetan Plateau (in Chinese). J Glaciol Geocryol, 2005, 27: 622-640 [王一博, 王根绪, 沈永平, 等. 青藏高原高寒区草地生态环境系统退化研究. 冰川冻土, 2005, 27: 622640]

16 Gao Q Z, Wan Y F, Xu H M, et al. Alpine grassland degradation index and its response to recent climate variability in Northern Tibet, China. Quat Int, 2010, 226: 143-150

17 Wen L, Dong S, Li Y, et al. The impact of land degradation on the C pools in alpine grasslands of the Qinghai-Tibet Plateau. Plant Soil, 2013, 368: 329-340

18 Zhang W, Xue X, Peng F, et al. Meta-analysis of the effects of grassland degradation on plant and soil properties in the alpine meadows of the Qinghai-Tibetan Plateau. Glob Ecol Conserv, 2019, 20: e00774

19 Jiang S J, Feng T J, Liu G H, et al. A bibliometric analysis of the application of grassland ecological restoration technology (in Chinese). Pratac Sci, 2020, 37: 1-18 [蒋胜竞, 冯天骄, 刘国华, 等. 草地生态修复技术应用的文献计量分析. 草业科学, 2020, 37: 1-18]

20 Zhou H K, Yao B Q, Yu L, et al. Degraded Succession and Ecological Restoration of Alpine Grassland in Three-River Source Region (in Chinese). Beijing: Science Press, 2016 [周华坤, 姚步青, 于龙, 等. 三江源区高寒草地退化演替与生态恢复. 北京: 科学出版社, 2016]

21 Chu C J, Weiner J, Maestre F T, et al. Positive interactions can increase size inequality in plant populations. J Ecol, 2009, 97: 1401-1407

22 Loreau M, Naeem S, Inchausti P. Biodiversity and Ecosystem Functioning: Synthesis and Perspectives. Oxford: Oxford University Press, 2002. 7991

23 Ives A R, Carpenter S R. Stability and diversity of ecosystems. Science, 2007, 317: 58-62

24 Fang J Y, Jing H C, Zhang W H, et al. The concept of "Grass-based Livestock Husbandry" and its practice in Hulun Buir, Inner Mongolia (in Chinese). Chin Sci Bull, 2018, 63: 1619-1631 [方精云, 景海春, 张文浩, 等. 论草牧业的理论体系及其实践. 科学通报, 2018, 63: 1619-1631]

25 Bai Y, Han X, Wu J, et al. Ecosystem stability and compensatory effects in the Inner Mongolia grassland. Nature, 2004, 431: 181-184

26 Loreau M. From Populations to Ecosystems: Theoretical Foundations for a New Ecological Synthesis. Princeton: Princeton University Press, 2010

27 Isbell F, Craven D, Connolly J, et al. Biodiversity increases the resistance of ecosystem productivity to climate extremes. Nature, 2015, 526: 574577

28 Shi Y, Wang Y, Ma Y, et al. Field-based observations of regional-scale, temporal variation in net primary production in Tibetan alpine grasslands. Biogeosciences, 2014, 11: 2003-2016

29 Liu H, Mi Z, Lin L, et al. Shifting plant species composition in response to climate change stabilizes grassland primary production. Proc Natl Acad Sci USA, 2018, 115: 4051-4056

30 Tilman D, Downing J A. Biodiversity and stability in grasslands. Nature, 1994, 367: 363-365

31 Flöder S, Jaschinski S, Wells G, et al. Dominance and compensatory growth in phytoplankton communities under salinity stress. J Exp Mar Biol Ecol, 2010, 395: 223-231

32 Hautier Y, Seabloom E W, Borer E T, et al. Eutrophication weakens stabilizing effects of diversity in natural grasslands. Nature, 2014, 508: 521525

33 Naeem S, Li S. Biodiversity enhances ecosystem reliability. Nature, 1997, 390: 507-509

34 Tilman D. The ecological consequences of changes in biodiversity: A search for general principles. Ecology, 1999, 80: 1455-1474

35 Tilman D, Reich P B, Knops J M H. Biodiversity and ecosystem stability in a decade-long grassland experiment. Nature, 2006, 441: 629-632

36 Blüthgen N, Simons N, Jung K, et al. Land use imperils plant and animal community stability through changes in asynchrony rather than diversity. Nat Commun, 2016, 7: 10697

37 Yachi S, Loreau M. Biodiversity and ecosystem productivity in a fluctuating environment: The insurance hypothesis. Proc Natl Acad Sci USA, 1999, 96: 1463-1468

38 Jing X, Sanders N J, Shi Y, et al. The links between ecosystem multifunctionality and above- and belowground biodiversity are mediated by climate. Nat Commun, 2015, 6: 8159

39 Xu W, Ma Z Y, Jing X, et al. Biodiversity and ecosystem multifunctionality: Advances and perspectives (in Chinese). Biodiver Sci, 2016, 24: 5571 [徐炜, 马志远, 井新, 等. 生物多样性与生态系统多功能性: 进展与展望. 生物多样性, 2016, 24: 55-71]

40 Manning P, van der Plas F, Soliveres S, et al. Redefining ecosystem multifunctionality. Nat Ecol Evol, 2018, 2: 427-436

41 Zhang X S, Tang H P, Dong X B, et al. The dilemma of steppe and its transformation in China (in Chinese). Chin Sci Bull, 2016, 61: 165-177 [张 新时, 唐海萍, 董孝斌, 等. 中国草原的困境及其转型. 科学通报, 2016, 61: 165-177] 
42 Xiao Y, Xie G D, An K. The function and economic value of soil conservation of ecosystems in Qinghai-Tibet Plateau (in Chinese). Acta Ecol Sin, 2003, 23: 2367-2378 [肖玉, 谢高地, 安凯. 青藏高原生态系统土壤保持功能及其价值. 生态学报, 2003, 23: 2367-2378]

43 Xie G D, Lu C X, Leng Y F, et al. Ecological assets valuation of the Tibetan Plateau (in Chinese). J Nat Resour, 2003, 18: 189-196 [谢高地, 鲁春 霞, 冷允法, 等. 青藏高原生态资产的价值评估. 自然资源学报, 2003, 18: 189-196]

44 Sun H L, Zheng D, Yao T D, et al. Protection and construction of the national ecological security shelter zone on Tibetan Plateau (in Chinese). Acta Geogr Sin, 2012, 67: 3-12 [孙鸿烈, 郑度, 姚檀栋, 等. 青藏高原国家生态安全屏障保护与建设. 地理学报, 2012, 67: 3-12]

45 Tilman D, Lehman C L, Thomson K T. Plant diversity and ecosystem productivity: Theoretical considerations. Proc Natl Acad Sci USA, 1997, 94: 1857-1861

46 Loreau M. Biodiversity and ecosystem functioning: Recent theoretical advances. Oikos, 2000, 91: 3-17

47 Kinzig A P, Pacala S W, Tilman D. The Functional Consequences of Biodiversity: Empirical Progress and Theoretical Extensions. Princeton: Princeton University Press, 2001

48 Dong S K, Tang L, Zhang X F, et al. Y. Relationship between plant species diversity and functional diversity in alpine grasslands (in Chinese). Acta Ecol Sin, 2017, 37: 1472-1483 [董世鬼, 汤琳, 张相锋, 等. 高寒草地植物物种多样性与功能多样性的关系. 生态学报, 2017, 37: 1472-1483]

49 Hooper D U, Chapin Iii F S, Ewel J J, et al. Effects of biodiversity on ecosystem functioning: A consensus of current knowledge. Ecol Monogr, 2005, 75: 3-35

50 Soliveres S, van der Plas F, Manning P, et al. Biodiversity at multiple trophic levels is needed for ecosystem multifunctionality. Nature, 2016, 536: 456-459

51 Weisser W W, Roscher C, Meyer S T, et al. Biodiversity effects on ecosystem functioning in a 15-year grassland experiment: Patterns, mechanisms, and open questions. Basic Appl Ecol, 2017, 23: 1-73

52 Meyer S T, Ptacnik R, Hillebrand H, et al. Biodiversity-multifunctionality relationships depend on identity and number of measured functions. Nat Ecol Evol, 2018, 2: 44-49

53 Loreau M, Hector A. Partitioning selection and complementarity in biodiversity experiments. Nature, 2001, 412: 72-76

54 Malkinson D, Tielbörger K. What does the stress-gradient hypothesis predict? Resolving the discrepancies. Oikos, 2010, 119: 1546-1552

55 Bertness M D, Callaway R. Positive interactions in communities. Trends Ecol Evol, 1994, 9: 191-193

56 Callaway R M. Positive interactions in plant communities and the individualistic-continuum concept. Oecologia, 1997, 112: 143-149

57 Filotas E, Grant M, Parrott L, et al. The effect of positive interactions on community structure in a multi-species metacommunity model along an environmental gradient. Ecol Model, 2010, 221: 885-894

58 Wang X, Michalet R, Liu Z, et al. Stature of dependent forbs is more related to the direct and indirect above- and below-ground effects of a subalpine shrub than are foliage traits. J Veg Sci, 2019, 30: 403-412

59 Choler P, Michalet R, Callaway R M. Facilitation and competition on gradients in alpine plant communities. Ecology, 2001, 82: 3295-3308

60 Callaway R M, Brooker R W, Choler P, et al. Positive interactions among alpine plants increase with stress. Nature, 2002, 417: 844-848

61 Holzapfel C, Tielbörger K, Parag H A, et al. Annual plant-shrub interactions along an aridity gradient. Basic Appl Ecol, 2006, 7: 268-279

62 Michalet R. Is facilitation in arid environments the result of direct complex interactions? New Phytol, 2006, 169: 3-6

63 Brooker R W, Maestre F T, Callaway R M, et al. Facilitation in plant communities: The past, the present, and the future. J Ecol, 2008, 96: 18-34

64 Butterfield B J, Callaway R M. A functional comparative approach to facilitation and its context dependence. Funct Ecol, 2013, 27: 907-917

65 Simberloff D, Holle B V. Positive Interactions of nonindigenous species: Invasional meltdown? Biol Invas, 1999, 1: 21-32

66 Richardson D M, Allsopp N, D’Antonio C M, et al. Plant invasions-The role of mutualisms. Biol Rev, 2000, 75: 65-93

67 Rantala-Sykes B, Campbell D. Should I pick that? A scoring tool to prioritize and valuate native wild seed for restoration. Restor Ecol, 2019, 27: 9 14

68 De Vitis M, Abbandonato H, Dixon K, et al. The European native seed industry: Characterization and perspectives in grassland restoration. Sustainability, 2017, 9: 1682

69 Shinneman D J, Baker W L, Lyon P. Ecological restoration needs derived from reference conditions for a semi-arid landscape in Western Colorado, USA. J Arid Environ, 2008, 72: 207-227

70 Van Ruijven J, Berendse F. Diversity enhances community recovery, but not resistance, after drought. J Ecol, 2010, 98: 81-86

71 Stevenson M J, Ward L K, Pywell R F. Re-creating semi-natural communities: Vacuum harvesting and hand collection of seed on calcareous grassland. Restor Ecol, 1997, 5: 66-76

72 Nevill P G, Tomlinson S, Elliott C P, et al. Seed production areas for the global restoration challenge. Ecol Evol, 2016, 6: 7490-7497

73 Güsewell S, Verhoeven J T A. Litter N:P ratios indicate whether N or P limits the decomposability of graminoid leaf litter. Plant Soil, 2006, 287: 131-143

74 Sardans J, Rivas-Ubach A, Peñuelas J. The elemental stoichiometry of aquatic and terrestrial ecosystems and its relationships with organismic lifestyle and ecosystem structure and function: A review and perspectives. Biogeochemistry, 2012, 111: 1-39 
75 Liu A R, Yang T, Xu W, et al. Status, issues and prospects of belowground biodiversity on the Tibetan alpine grassland (in Chinese). Biodiver Sci, 2018, 26: 972-987 [刘安榕, 杨腾, 徐炜, 等. 青藏高原高寒草地地下生物多样性: 进展、问题与展望. 生物多样性, 2018, 26: 972-987]

76 Li J H, Li X P, Lu H, et al. Characteristics of, and the correlation between, vegetation and $\mathrm{N}$-fixing soil bacteria in alpine grassland showing various degrees of degradation (in Chinese). Acta Ecol Sin, 2017, 37: 3647-3654 [李建宏, 李雪萍, 卢虎, 等. 高寒地区不同退化草地植被特性和土壤固 氮菌群特性及其相关性. 生态学报, 2017, 37: 3647-3654]

77 Wang D L, Wang L. A new perspective on the concept of grassland management (in Chinese). Chin Sci Bull, 2019, 64: 1106-1113 [王德利, 王岭. 草地管理概念的新释义. 科学通报, 2019, 64: 1106-1113]

78 Tilman D, Isbell F, Cowles J M. Biodiversity and ecosystem functioning. Annu Rev Ecol Evol Syst, 2014, 45: 471-493 


\title{
Close-to-nature restoration of degraded alpine grasslands: Theoretical basis and technical approach
}

\author{
Jinsheng $\mathrm{He}^{1,3}$, Haiyan $\mathrm{Bu}^{2}$, Xiaowen $\mathrm{Hu}^{1}$, Yanhao Feng ${ }^{1}$, Shouli $\mathrm{Li}^{1}$, Jianxiao Zhu ${ }^{1}$, Guohua Liu ${ }^{4}$, \\ Yanrong Wang ${ }^{1} \&$ Zhibiao Nan ${ }^{1}$ \\ ${ }^{1}$ State Key Laboratory of Grassland Agro-ecosystems, College of Pastoral Agriculture Science and Technology, Lanzhou University, Lanzhou 730020, \\ China; \\ ${ }^{2}$ State Key Laboratory of Grassland Agro-ecosystems, School of Life Science, Lanzhou University, Lanzhou 730000, China; \\ ${ }^{3}$ College of Urban and Environmental Science, Peking University, Beijing 100871, China; \\ ${ }^{4}$ State Key Laboratory of Urban and Regional Ecology, Research Center for Eco-Environmental Sciences, Chinese Academy of Sciences, Beijing \\ 100085, China \\ *Corresponding author, E-mail: jshe@pku.edu.cn
}

The alpine grasslands on the Tibetan Plateau, which account for about $40 \%$ of the total grassland area in China, serve as an important ecological barrier to protect China's water resources and for ecological security. Although the vegetation activity of alpine grasslands on the Tibetan Plateau has been overall improving during the past decades, most of the grasslands are still suffering from varying degrees of degradation, with some part even deteriorating. In the present protection and construction of ecological barriers on the Tibetan Plateau, the restoration of the degraded alpine grasslands through current technical approaches often end up with low stability and sustainability, and the ecosystem multifunctionality and multiserviceability of the grasslands are often difficult to be fully recovered. This is mainly because the present approaches rarely draw support from the natural restoration processes, along with the technical limitations of optimizing the assembly and supplementary sowing with appropriate native grass species that are often rare, and of improving soil quality using microbial fertilizer and nutrients. Therefore, it is urgent to develop an effective and sustainable restoration approach of the degraded alpine grasslands.

The primary tasks of close-to-nature restoration with ecological conservation as its premise focuses on maintaining biodiversity and enhancing ecosystem multifunctionality and multiserviceability. Close-to-nature restoration adopts traditional artificial restoration approaches and relies on natural ecological processes to achieve sustainable ecological restoration. It focuses on "based on nature" and "return to nature", and realizes sustainable restoration through the selfregulating function of natural ecosystem. Therefore, ecosystems that are restored through close-to-nature restoration may maintain higher biodiversity, provide more ecosystem functions and services, and increase resilience to natural disasters. This paper proposes to apply the close-to-nature restoration to recover degraded alpine grasslands on the Tibetan Plateau, and addresses why it is a natural choice on the basis of ecological theories with respect to biodiversity and the multifunctionality and multiserviceability of ecosystems, as well as the uniqueness of alpine grasslands on the Tibetan Plateau. Based on this, this paper further proposes that seed multiplication, and assembly and supplementary sowing technology of native grassland species are the bottlenecks to the close-to-nature restoration of alpine grasslands, and that the combination of soil nutrients and microbial regulation is an essential supplementary measure. This study, which integrates the theory of close-to-nature restoration and the corresponding techniques, hopefully can provide a nature-based solution for the restoration of the degraded alpine grassland ecosystems on the Tibetan Plateau.

close-to-nature restoration, alpine grassland, biodiversity, ecosystem multifunctionality, ecosystem multiserviceability, native grass

doi: 10.1360/TB-2020-0405 